Article

\title{
Pruning and Training Systems Impact Yield and Cold Hardiness of 'Marion' Trailing Blackberry
}

\author{
Bernadine C. Strik \\ Department of Horticulture, Oregon State University, 4017 ALS, Corvallis, OR 97331, USA; \\ bernadine.strik@oregonstate.edu; Tel.: +1-541-737-5434
}

Received: 8 August 2018; Accepted: 24 August 2018; Published: 1 September 2018

\begin{abstract}
The floricane-fruiting, trailing blackberry (Rubus L. subgenus Rubus, Watson) cultivar Marion was evaluated in two plantings for the impact of floricane pruning date. This included leaving the dead canes unpruned and training new primocanes over the dead wood (new-over-old), primocane topping and suppression date in alternate year (AY) and every year (EY) production systems at various planting densities. The presence of primocanes during fruit development did not affect yield of the floricane in the current season but suppressing primocanes to June 30 in Oregon, USA, led to insufficient time for primocane growth, reducing yield of the floricane the following year by $36 \%$ relative to no primocane suppression. Pruning out senescing floricanes immediately after fruit harvest or later-thus allowing more time for remobilization of nutrients or reserves-had no impact on yield. However, yield in the new-over-old system was higher, likely due to less training damage to primocanes in this treatment. All of the AY treatments studied led to lower berry weight compared to EY production but this has not been an issue in the processed fruit market to date. Plants in AY production produced more canes per plant than in EY but at the industry standard spacing of $1.5 \mathrm{~m}$, AY plants yielded only $60 \%$ to $66 \%$ more than EY plants in these studies, despite evidence of plants in AY production having greater cold hardiness. There was no significant effect of planting at higher density $(0.6$ and $0.9 \mathrm{~m})$ on cumulative yield over 4 years. However, planting at $0.6 \mathrm{~m}$ and topping the primocanes to the top trellis wire $(1.8 \mathrm{~m})$ increased yield significantly compared to other AY treatments. This alternative production system may offer economic advantages to the $1.5 \mathrm{~m} \mathrm{EY}$ or AY production systems through reducing management costs and allowing for mechanical pruning and training.
\end{abstract}

Keywords: primocane suppression; machine harvest; winter injury; Rubus; new-over-old pruning

\section{Introduction}

Oregon is the leading producer of trailing blackberry (Rubus L. subgenus Rubus, Watson) in the USA, with about 2500 ha harvested in 2016 [1]. Approximately 90\% of the trailing blackberry production in Oregon is harvested by over-the-row machines for the processed market [2]. 'Marion,' a cultivar released from the United States Department of Agriculture-Agricultural Research Service and Oregon State University cooperative breeding program in 1956, is recognized for its exceptional fruit quality for processing [3,4] and is still widely grown. However, 'Marion' blackberry canes are thorny increasing the risk of thorn contaminants in the machine-harvested product, a liability issue for fruit packing companies [5]. While growers do have some cultural methods for reducing the risk of thorn contamination in this cultivar, such as using over-the-row machine harvesters to brush non-senescent thorny petioles from the plants in the late winter [5], genetically thornless cultivars, such as 'Black Diamond' and 'Columbia Star,' are currently more popular choices for new plantings [3].

The canes of 'Marion' and other trailing blackberry cultivars are not self-supporting making pruning and training a very important aspect of economically sustainable production [6,7]. Canes are 
biennial with the primocanes vegetative in the first year of growth, overwintering and then becoming floricanes and fruiting in their second year. Floricanes senesce after fruiting is complete [8].

'Marion' plantings are grown in either an every-year (EY) or an alternate-year (AY) production system. In EY systems, fruit are harvested each year. New primocanes are carefully trained on the ground, under the floricane canopy. After fruit harvest is complete, senescent floricanes are pruned just above crown height and are removed from the trellis, a practice called caning out. Primocanes are then trained onto the trellis wires in late August or in February. A small proportion of growers are not caning out and are training the primocanes over the dead floricane canopy, a system called new-over-old; this saves them labor costs associated with caning out and primocane training [9].

In AY production, fruit harvest occurs every other year on a given section of land. After fruit harvest in what is called the on-year, plantings are left un-pruned until autumn when all canes are removed by mechanically cutting just above crown height. The planting then has no canes present over the winter (and no risk of winter cold injury). The following year, there is no fruit production (the off-year) because only primocanes are present. Primocanes are trained to the trellis as they grow, reducing training costs [6]. In a given year, growers who use this production system will have half their planting fruiting in the on-year and half in the off-year. In the off-year of an AY system, more primocanes grow per plant than in the EY system, because primocanes in the EY system compete for resources with floricanes [10]. The yield of the AY system is about $80 \%$ of the EY production system, depending on cultivar [9], however there are cost savings [6] and less risk of winter cold injury (historically) for AY systems [11].

In EY production systems, most growers train primocanes in February, because leaving the canes on the ground for most of the winter, reduces the exposure of canes to cold desiccating winds and reduces the risk of winter cold damage [11]. In AY production, primocanes that have been trained as they grow in the off-year are more cold hardy than primocanes that grew in the presence of floricanes in EY production systems [9,11-13]. Lack of sufficient cold hardiness is a major production problem preventing sustainable yield of 'Marion' over an extended period of time [4].

Training time in EY production systems may have an impact on yield and berry weight. Bell et al. [14] theorized that training primocanes in August improved the light exposure and carbohydrate status of the primocanes, compared to leaving canes on the ground most of the winter and training in February, thus increasing subsequent bud break. Flower bud initiation and differentiation occur in early autumn in trailing blackberry [15]; good light exposure during this period has improved the number of flowers per lateral in 'Marion' in some cases [14] but not others [16].

Primocane suppression using contact herbicides [17] is a common practice in EY and the on-year of AY production systems. Primocane suppression removes (or kills) the first flush of primocane growth. The plants respond by producing another flush of primocanes $[8,9]$. In red raspberry (Rubus idaeus L.), primocane suppression increases current-season yield [18-22] due to competition of resources between primocanes and floricanes. In trailing blackberry, there has been no research on whether primocane growth limits resources available for the floricanes. However, delaying primocane growth relative to fruit harvest date, increases machine harvest efficiency because the catcher plates on the harvester fit more tightly around the base of the plant [2]. Primocane suppression can be done mechanically using either secateurs in EY systems or sickle bars or cutters in the off-year of AY production - the former is too expensive for processed market production systems. Bell et al. [12] found that mechanical primocane suppression in the off-year increased subsequent cold hardiness of the next flush of primocanes in AY production. This practice can be done for a relatively low cost (personal observation) but selection of the date for primocane suppression is important because the remaining growing season affects cane length of the next flush of primocanes prior to dormancy [14].

The objectives of these studies were to assess the impact of primocane growth on floricane production and various combinations of pruning systems. This included August or February training and the new-over-old system in EY production, AY production, planting density and primocane 
suppression date in AY systems on plant growth, yield and berry weight over several years in 'Marion' blackberry.

\section{Materials and Methods}

The studies were conducted at Oregon State University's North Willamette Research and Extension Center, Aurora, OR, USA (lat. $45^{\circ} 16^{\prime} \mathrm{N}$, long. $122^{\circ} 45^{\prime} \mathrm{W}$; USDA hardiness zone 8b [23]; historical weather records for this site can be viewed at U.S. Department of Interior [24]).

\subsection{Experiments 1 and 2}

These experiments were conducted in a mature, four-year-old planting of 'Marion' trailing blackberry grown on a Willamette silt loam, classified as a fine-silty, mixed, superactive mesic Pachic Ultic Argixeroll. Plant spacing was $1.8 \mathrm{~m}$ in the row with $3 \mathrm{~m}$ between rows (1852 plants/ha). A permanent grass cover crop grew between the rows. The in-row area ( 1-m-wide) was maintained (bare soil) with pre-emergent herbicides and hoeing, as needed. Irrigation was with overhead sprinklers, once or twice weekly, as needed to provide approximately 3.8 to $5.1 \mathrm{~cm}$ of water per week if rainfall was insufficient, depending on plant water needs.

Fertilizer nutrients were applied per standard recommendations [25] and using results from soil and or tissue analysis. During the study period, $79 \mathrm{~kg} \cdot \mathrm{ha}^{-1} \mathrm{~N}$ was applied in a split application with $34 \mathrm{~kg} \cdot \mathrm{ha}^{-1}$ in early April ( $\left.8 \mathrm{~N}-7.5 \mathrm{P}-14 \mathrm{~K}\right)$ and $45 \mathrm{~kg} \cdot \mathrm{ha}^{-1}$ in late May $(40 \mathrm{~N}-0 \mathrm{P}-0 \mathrm{~K}-5 \mathrm{Mg})$. These granular fertilizers were broadcast within the in-row area and were washed into the soil through rainfall (data not shown). No fungicides or insecticides were applied during the study.

Plants were trained on a two-wire vertical trellis system with the wires attached to steel posts at $1.0 \mathrm{~m}$ and $1.6 \mathrm{~m}$ above the ground. New primocanes were bundled and trained along the ground in the row, below the floricane canopy. Primocanes were trained to the trellis wires in late August or February, depending on treatment (see below), by dividing the primocanes produced by each plant into two bundles and looping half in one direction from the upper to lower trellis wire and bringing it back towards the plant with one or two twists; the other half was looped in the opposite direction.

In Expt. 1, pruning and training treatments from 1996-1998 were:

1. Primocane suppression through the early season coupled with immediate floricane removal after fruiting $(-\mathrm{PeF})$. In this treatment, emerging primocanes were removed by pruning at soil level when $\sim 0.15 \mathrm{~m}$ tall from spring through the early stages of fruit development; primocanes emerging from the crown after June 30 were retained. Primocanes were trained onto the trellis wires in February, as described above. Senescing floricanes were removed by pruning to just above crown height (caning out) immediately after last fruit harvest (1 August 1996 and 23 July 1997).

2. No primocane suppression, immediate floricane removal after harvest $(+\mathrm{PeF})$. All primocanes that emerged were retained. Caning out and primocane training were done in late July-early August and February, respectively, as for treatment 1.

3. No primocane suppression, late floricane removal (+PIF). All primocanes were retained and were trained as per treatment 2 (in February). Caning out was delayed until 30 August 1996 and 30 October 1997.

4. No primocane suppression, no floricane removal (+P+F; new-over-old pruning system). Floricanes were not pruned from the trellis after senescence (no caning out). All primocanes were retained and any growing up into the canopy (trapped by floricanes) were tucked, as needed. Primocanes were otherwise trained along the ground in the row and were trained over the dead floricane canopy in February.

5. No primocane suppression, no floricanes present in 1996 (off year of an alternate year fruiting system) $(+\mathrm{P}-\mathrm{F})$. Primocanes were trained as they grew in 1996, the off year, as per standard commercial practice [26]. This treatment was only harvested for fruit in 1997, the on year. 
In all treatments, fruit were harvested weekly, by hand, in 1996 and by machine (Littau Harvesters Inc., Stayton, OR, USA) from 1997-1998 for the four-week fruiting season, mainly during the month of July, depending on year. Machine harvest occurred approximately twice per week, depending on weather. Total harvested yield for the season was measured and yield per plant calculated. On each harvest date, a 25-berry sample was collected from the harvested fruit and weighed; a seasonal, weighted berry average mass was calculated. The number of floricanes per plant was counted prior to the fruiting season in 1996 and 1997. Percent bud break on the floricanes was estimated by counting the total number of nodes and emerging laterals in a $1 \mathrm{~m}^{2}$ section of the canopy located between the upper and lower training wire. In 1996-1997 and 1998 (except for treatment 5), data were collected on the number of fruit per lateral immediately prior to first harvest by randomly selecting 10 laterals on each side of the plant canopy (row) per plot and counting the number of fruit present; the average number of fruit per lateral was calculated.

In Expt. 2, starting after fruit harvest in 1998 through 2000, treatments were continued or were modified in the same planting as follows:

1. No primocane suppression, immediate floricane removal after fruit harvest $(+\mathrm{PeF})$. Formerly, treatment 2 of Expt. 1 (see above) and continued in the same plots.

2. No primocane suppression, no floricane removal (new-over-old, August-trained). Floricanes were not pruned from the trellis after senescence (no caning out). Any primocanes growing up into the canopy (trapped by floricanes) were tucked, as needed. Primocanes were otherwise maintained along the ground in the row and were trained over the dead floricane canopy in August. This treatment continued in the same plots as treatment 5 of Expt. 1 (above). Note that the treatment was changed from AY production to EY production between 1997 and 1998.

3. No primocane suppression, no floricane removal (new-over-old, February-trained). Same as treatment 2 of Expt. 2 but primocanes were trained over the dead floricane canopy in February. In the same plots as the former treatment 4 (above) but primocane training time was changed from February to August.

While Expt. 2 continued in the same field as Expt. 1, treatments (as noted above) either continued with no change in management (Treatments 1 and 3 in Expt. 2) or were chosen to minimize impact (Treatment 2; was formerly AY and thus had a larger canopy).

Fruit were harvested by machine and data on total yield, berry weight and percent bud break were collected as described above. In spring (mid-April to early May 1998-2000, depending on year), rate of growth was evaluated by measuring the length of 20 fruiting laterals (10 on each side of the row or canopy) for each experimental unit. A 2-kg-subsample of machine-harvested fruit was randomly collected on each harvest date by placing a container at the end of the sorting belt on the machine harvester to catch fruit and any debris. The presence of petioles (whole or portion) and individual large ( $>2 \mathrm{~mm}$ long) and small thorns ( $<2 \mathrm{~mm}$ long) was determined by placing the sample on a light table; thorns in each category were counted. In addition, the non-marketable or cull fruit (unripe; physical damage; rot) that passed by the fan system on the machine harvester was placed in a container and the proportion of the total yield that was non-marketable was calculated for each plot.

In both experiments, there were four replicates of each experimental unit (a five-plant plot) arranged in a completely random design. There was a 3-m-long unplanted space between adjacent experimental units to allow for clearing of the machine harvester between treatment plots. The planting was flanked by guard rows.

Data were analyzed by analysis of variance using the GLM procedure in SAS (SAS Institute Inc., Cary, NC, USA) for pruning/training treatment effects on each measured variable. Treatment means were compared using a Fisher's protected least significant difference (LSD) test. 


\subsection{Experiment 3}

A new planting of 'Marion' was established in April 2000 using standard tissue-cultured plug plants. Rows were spaced $3 \mathrm{~m}$ apart. Plant spacing in the row was either $0.6,0.9$, or $1.5 \mathrm{~m}$, depending on treatment (see below). Plants were irrigated using drip tubing with $3.8 \mathrm{~L} \cdot \mathrm{h}^{-1}$ emitters spaced $0.76 \mathrm{~m}$ apart. The tubing was suspended on a trellis wire $\sim 0.45 \mathrm{~m}$ above the soil surface. Irrigation was applied weekly as needed from May to September to meet or exceed $100 \%$ of the estimated crop evapotranspiration [27]. Plants were fertilized each spring using standard practices [25] and any pests controlled, as needed, using approved products [17,28,29].

The primocanes that grew in the planting year were removed by pruning each plant to just above crown height in February 2001—a common commercial practice in plantings established using plugs [2]. In 2001, primocanes were trained as they grew to a standard two-wire trellis as described previously. In-row spacing and primocane management treatments were as follows:

1. $0.6 \mathrm{~m}$ in-row spacing, AY production. Primocanes topped at $1.8 \mathrm{~m}$ once they grew approximately $0.15 \mathrm{~m}$ beyond the top trellis wire, during the growing season (in mid- to late-June).

2. $0.6 \mathrm{~m}$ in-row spacing, AY production. Primocanes not topped.

3. $0.9 \mathrm{~m}$ in-row spacing, AY production. Primocanes not topped.

4. $1.5 \mathrm{~m}$ in-row spacing, AY production. Primocanes not topped.

5. $1.5 \mathrm{~m}$ in-row spacing, EY production with February-training of primocanes (industry standard [2,9]). Primocanes not topped.

Each treatment plot consisted of a 6.1-m-long row of plants, replicated five times in a randomized complete block design. Each plot or experimental unit was separated from the adjacent plot by $3 \mathrm{~m}$ of unplanted space to allow for clearing of the machine harvester between plots. In 2001, all treatment plants had only primocanes that were trained as they grew; primocanes were not topped in treatment 1 . The AY plots were designed such that half of each plot was in the on-year (fruiting) and the other half in the off-year in any given year. In 2004, primocane suppression was added to the off-year of some of the AY treatments based on observations of primocane growth and research findings of Bell et al. [12,14]. Primocanes were suppressed by cutting off all canes that had grown to just above crown height using pruning shears. This was done in mid- to late-April in treatment 4 and early to late-May in treatments 2 and 3, depending on year. After the existing primocanes were cut to crown height, the next flush of primocanes was trained as they grew. There was no primocane suppression in treatments 1 and 5 .

The planting was harvested from 2002-2008 using an over-the-row machine harvester (Littau Harvesters Inc., Stayton, OR, USA). From 2002-2007, data were collected on yield, berry weight and the number of petioles per $2 \mathrm{~kg}$ of fruit (thorns, as described previously) per harvest date. Floricane number per plant was counted in winter (average of two plants per plot). After fruit harvest ( August), two floricanes were removed on each of two plants per plot and data collected on cane length and the number of nodes, fruiting laterals per cane and fruit per lateral (on three laterals per cane). Percent bud break and average fruit number per lateral were calculated. In 2008, only data on yield and berry weight per harvest date were collected.

\section{Results and Discussion}

\subsection{Experiment 1}

There was no effect of treatment on yield and the measured components in 1996 (Table 1), because all plots were similarly managed the prior year. However, there was also no effect of removing primocanes continuously from spring through early fruit development (June $30 ;-\mathrm{PeF}$ ) on yield or berry weight, as compared to retaining the primocanes and training them under the plant canopy during this period. It appears that in trailing blackberry, the presence of primocanes during fruit development does not reduce floricane yield. In contrast, primocane suppression increases current-season yield of red 
raspberry [18-22]. It is possible that the difference between these crops is related to cane architecture and growth. In trailing blackberry, the primocanes do not grow within the canopy competing for light as in red raspberry. In addition, most of the primocane growth in 'Marion' occurs after the fruit-filling period, reducing the potential for competition for resources between cane types [13]. Retaining only the primocanes that grew after June $30(-\mathrm{PeF}$; Table 1$)$ did not reduce the number of canes per plant (became floricanes in 1997) but did reduce yield the following year by $36 \%$ compared to plants where primocanes were not suppressed and had all season to grow $(+\mathrm{PeF})$. This yield effect occurred despite primocanes in the $-\mathrm{PeF}$ treatment initiating more flowers or fruit per lateral compared to those in the + PeF treatment (1997; Table 1).

Table 1. Effect of primocane suppression and training time and floricane pruning time on yield components of 'Marion' trailing blackberry from 1996-1998 at Oregon State University's North Willamette Research and Extension Center $(n=4)$.

\begin{tabular}{|c|c|c|c|c|c|c|}
\hline \multirow{2}{*}{ Treatment $^{1}$} & Floricanes & Bud Break & Fruit & Berry wt. & Yield & Non-Marketable \\
\hline & (no./plant) & $(\%)$ & (no./lateral) & (g) & (kg/plant) & Fruit (\%) \\
\hline & \multicolumn{6}{|c|}{1996} \\
\hline 1. Primocanes suppressed; early floricane removal $(-\mathrm{PeF})$ & 7.2 & 51.2 & 10.4 & 4.83 & 3.69 & na \\
\hline 3. No primocanes suppression; no floricane removal (+PIF) & 6.5 & 36.7 & 9.9 & 4.61 & 3.66 & na \\
\hline 4. Primocanes suppressed; early floricane removal $(+\mathrm{P}+\mathrm{F})$ & 6.7 & $\mathrm{Na}^{3}$ & na & 4.83 & 4.16 & na \\
\hline 5. No primocanes suppression; alternate year (only fruiting in 1997) & 0 & na & na & na & na & na \\
\hline Significance $^{2}$ & \multicolumn{6}{|c|}{1997} \\
\hline 1. Primocanes suppressed; early floricane removal $(-\mathrm{PeF})$ & $8.2 b^{4}$ & $53.2 \mathrm{a}$ & $9.3 \mathrm{ab}$ & 4.95 & $2.89 \mathrm{c}$ & $5.1 \mathrm{ab}$ \\
\hline 2. No primocanes suppression; early floricane removal $(+\mathrm{PeF})$ & $8.0 \mathrm{~b}$ & $49.5 \mathrm{a}$ & $7.4 \mathrm{c}$ & 4.60 & $4.52 \mathrm{~b}$ & $4.1 \mathrm{bc}$ \\
\hline 3. No primocanes suppression; no floricane removal (+PIF) & $7.4 \mathrm{~b}$ & $33.2 \mathrm{~b}$ & $7.8 \mathrm{bc}$ & 4.83 & $3.64 \mathrm{bc}$ & $5.6 \mathrm{a}$ \\
\hline 4. Primocanes suppressed; early floricane removal $(+\mathrm{P}+\mathrm{F})$ & $7.7 \mathrm{~b}$ & na & $10.3 \mathrm{a}$ & 4.68 & $5.86 \mathrm{a}$ & $4.5 \mathrm{abc}$ \\
\hline 5. No primocanes suppression; alternate year (only fruiting in 1997) & $9.3 \mathrm{a}$ & na & $10.1 \mathrm{a}$ & 4.40 & $6.52 \mathrm{a}$ & $3.7 \mathrm{c}$ \\
\hline \multirow[t]{2}{*}{ Significance } & * & ** & * & NS & *** & * \\
\hline & \multicolumn{6}{|c|}{1998} \\
\hline 3. No primocanes suppression; no floricane removal (+PIF) & na & 61.0 & 8.8 & 4.25 & $2.11 \mathrm{a}$ & 7.4 \\
\hline 4. Primocanes suppressed; early floricane removal $(+\mathrm{P}+\mathrm{F})$ & na & 66.8 & 8.6 & 4.05 & $2.63 \mathrm{a}$ & 6.1 \\
\hline 5. No primocanes suppression; alternate year (only fruiting in 1997) & na & na & na & na & na & na \\
\hline Significance & - & NS & NS & NS & $* *$ & NS \\
\hline \multicolumn{7}{|c|}{$\begin{array}{l}{ }^{1} \text { In treatment } 1 \text {, primocanes were removed by pruning at ground level from early spring until June } 30 \text { of each year. } \\
\text { Senescing floricanes were removed immediately after harvest ( } 1 \text { August } 1996 \text { and } 23 \text { July 1997) in treatments } 1 \text { and } \\
\text { 2. Primocanes were not suppressed or removed at any time of the growing season in treatments } 2-5 \text {. Primocanes } \\
\text { were trained onto the trellis wires in February in treatments } 1-4 \text {. In treatment } 3 \text {, floricane removal was delayed } \\
\text { until } 30 \text { August in } 1996 \text { and } 30 \text { October in } 1997 \text {. Treatment } 5 \text { was in alternate year production with primocanes } \\
\text { trained to the trellis wires as they grew in } 1996 \text { and fruit harvest only in } 1997 \text { in this study; }{ }^{2} \mathrm{NS}=\text { non-significant; } \\
*^{* * * * *} \text { indicates significance at } p<0.05,0.01 \text { and } 0.001 \text {, respectively; }{ }^{3} \text { "na" indicates data not collected in that year } \\
\text { or treatment was not in the fruiting year (treatment } 5) ;{ }^{4} \text { Means followed by the same letter within year are not } \\
\text { significantly different }(p \geq 0.05) \text {. }\end{array}$} \\
\hline
\end{tabular}

Date of floricane removal after the fruiting season affected yield in 1997 and 1998 (Table 1). The most common time for floricanes to be removed in trailing blackberry is in late August, about 3 to 4 weeks after harvest of 'Marion' [9]. While some growers remove the floricanes immediately after the fruiting season, others are experimenting with leaving the dead floricanes within the canopy to save labor. In late August, floricanes contain as much as $20 \mathrm{~kg} \cdot \mathrm{ha}^{-1}$ of nitrogen $(\mathrm{N})$ and $10 \mathrm{~kg} \cdot \mathrm{ha}^{-1}$ of potassium [30-32]. Senescence of the floricanes occurs slowly after fruit harvest. Carbohydrates and mobile nutrients are likely remobilized from the senescing floricanes into the primocanes, crown and roots, as has been shown for $\mathrm{N}$ in 'Kotata' trailing blackberry [33] and in floricane-fruiting red raspberry [34]. For example, if the floricanes of 'Meeker' red raspberry were pruned in mid-September rather than in mid-August, the plant recovery of $\mathrm{N}$ from senescing floricanes increased by $6.2 \mathrm{~kg} \cdot \mathrm{ha}^{-1}$ [34]. Delaying pruning as long as possible, thus, allows greater time for remobilization of nutrients and possibly carbohydrates to storage tissues. However, in this study, there was no effect of removing floricanes early (late July or early August; $+\mathrm{PeF})$ compared to late $(+\mathrm{PlF})$, 30 August 1996 or 30 October 1997, on yield the subsequent year (Table 1). The highest yield in 1997 
was in plots where floricanes were not removed $(+\mathrm{P}+\mathrm{F})$. Since the floricanes would have had time to fully remobilize nutrients by October $30(+\mathrm{PlF})$, the likely reason for the unpruned treatment $(+\mathrm{P}+\mathrm{F})$ to have greater yield in 1997 is less training damage to primocanes. It is important to train primocanes carefully to the trellis wires to avoid kinking or damage, which reduce subsequent yield $[9,16]$. When primocanes either grew up through the canopy of the floricanes or could be trained over the dead floricane canopy, there was less training damage (personal observation).

In 1997, percent bud break was lower in the treatment where caning out was delayed the prior year $(+\mathrm{PlF})$ as compared to early caning out $(+\mathrm{PeF})$ with no significant effect on yield. While cane length was not measured in this experiment, it is possible that primocanes were longer in the +PIF treatment due to added resources as mentioned above. Percent bud break in 'Marion' decreases as cane length increases [14]. While there was a significant treatment effect on the proportion of non-marketable or cull fruit, there was no consistent effect among the EY fruiting treatments (treatments 1-4; Table 1). The proportion of cull fruit was relatively low. The AY treatment was in the off year in 1996, with primocanes trained as they grew and produced fruit in 1997 (Table 1). Without floricanes present in 1996, more primocanes grew per plant than in all other treatments, as shown by Cortell and Strik [13] in 'Marion' and by others in red raspberry [18,21,22,35].

The higher floricane number plus more fruit per lateral and greater berry weight in the AY treatment, increased yield compared to all treatments except for $+\mathrm{P}+\mathrm{F}$ (new-over-old). Yield in the on-year of the AY system was $60 \%$ greater than in the EY system (average of $+\mathrm{PeF}$ and $+\mathrm{PlF}$; Table 1 ).

Removing primocanes in the spring, up until 30 June 1997 (-PeF) reduced yield per plant in 1998, similar to the year prior. There was no effect of floricane pruning date or the new-over-old system on yield in 1998 (Table 1). Primocane management treatment had no effect on percent bud break, fruit number per lateral, berry weight and the percentage of cull fruit.

\subsection{Experiment 2}

Treatments where dead floricanes were retained (new-over-old), with primocanes either trained in August or February, were compared to removing the dead floricanes and training primocanes in February from 1998 to 2000 (Table 2).

Retaining the dead floricanes in the canopy $(+\mathrm{P}+\mathrm{F})$ increased percent bud break (except for $+\mathrm{P}+\mathrm{F}-\mathrm{Feb}$ in 2000), advanced fruiting lateral growth (except for $+\mathrm{P}+\mathrm{F}-\mathrm{Feb}$ in 1998) and increased yield in 1999 (except for $+\mathrm{P}+\mathrm{F}-\mathrm{Feb}$ ) and 2000 compared to removing floricanes after harvest and training primocanes in February (+PeF-Feb). In 2000, August training in the new-over-old treatment reduced berry weight compared to the other treatments but still had the greatest yield (Table 2). Training the new primocanes over the canopy of the dead floricanes may increase plant health (nutrient or carbohydrate status) because the floricanes remain on the plant through the full period of senescence but may also reduce primocane damage during training. 
Table 2. Effect of floricane removal (with or without) and primocane training time on yield components of 'Marion' trailing blackberry from 1998-2000 at Oregon State University's North Willamette Research and Extension Center $(n=4)$.

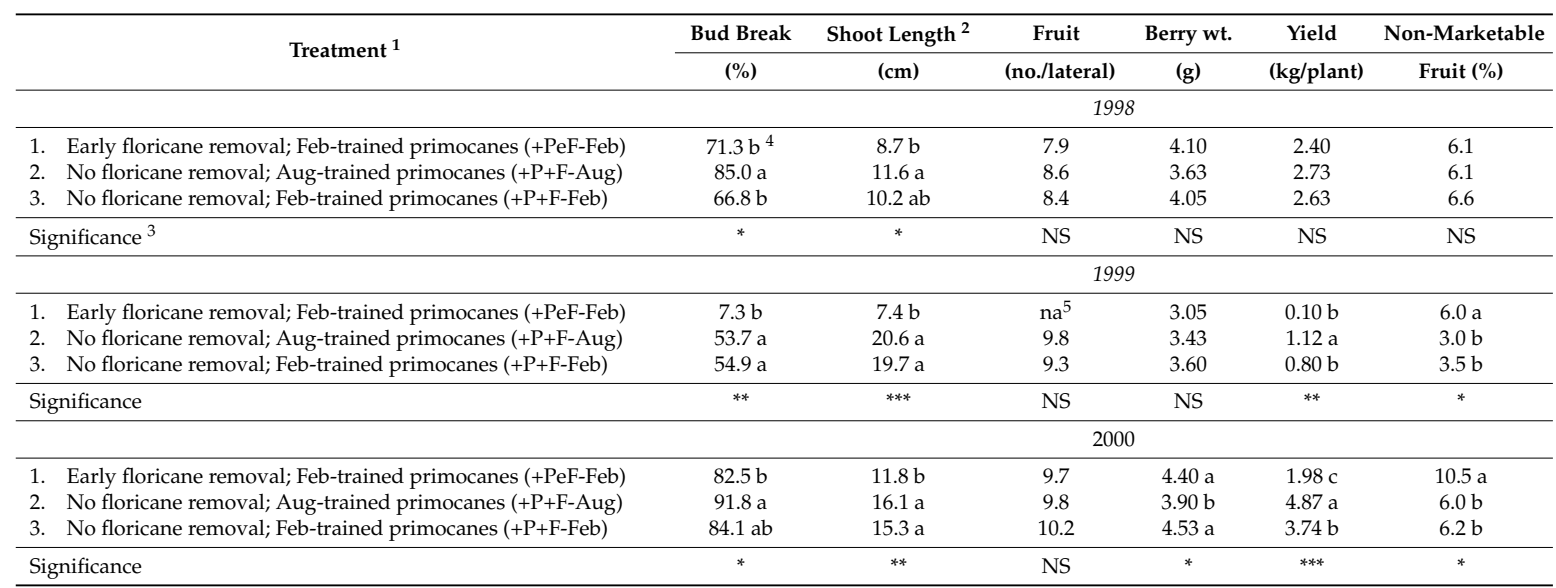

${ }^{1}$ In treatment 1 caning out was done immediately after harvest in late July to early August, depending on year. In treatments 2-3, the dead canes were left on the trellis and primocanes trained over the canopy of dead canes. Primocanes were trained either in August (treatment 2) or were left on the ground, in the row through winter until training in February (treatment 3$){ }^{2}$ Shoot length was measured in mid-April to early May of each year; ${ }^{3} \mathrm{NS}=$ non-significant; ${ }^{*}, * *, * * *$ indicates significance at $p<0.05,0.01$ and 0.001 , respectively; ${ }^{4}$ Means followed by the same letter within year are not significantly different $(p \geq 0.05)$.

Considering machine harvesting of these production systems, there was an expectation that leaving dead wood within the plant canopy would increase the presence of thorns (thorny petioles or single thorns that break off during harvest; [5]). We did find a higher presence of thorny petioles and large thorns in machine-harvested fruit from the new-over-old systems in one or two of the three years, respectively (Table 3). The exception was the high number of petioles found in the industry standard $(+\mathrm{PeF}-\mathrm{Feb})$ on the third harvest in 1999. It is possible that the reduced canopy size (as evidenced by the low yield; Table 2) led to excessive contact of the machine harvester's beater rods with the floricanes relative to the new-over-old treatments. Thorn contaminants were more prevalent in the third or last harvest than in the first two harvests (Table 3). The settings on the machine harvester are adjusted to increase the force to remove late-season fruit [2] and earlier harvests may partially dislodge petioles or thorns on the floricanes. The new-over-old pruning systems did have a lower percentage of cull fruit than the industry standard in 2 of 3 years (Table 2). 
Table 3. Effect of floricane removal and primocane training time on thorny contaminants in 'Marion' fruit harvested by machine on each of 4 times from 1998-2000 at Oregon State University's North Willamette Research and Extension Center $(n=4)$.

\begin{tabular}{|c|c|c|c|c|c|c|c|c|c|c|c|c|}
\hline \multirow{3}{*}{ Treatment $^{1}$} & \multirow{2}{*}{\multicolumn{4}{|c|}{$\begin{array}{c}\text { Thorny Petioles }^{2} \\
\text { Machine Harvest Number }^{3}\end{array}$}} & \multirow{2}{*}{\multicolumn{4}{|c|}{$\begin{array}{c}\text { Large Thorns }^{2} \\
\text { Machine Harvest Number }\end{array}$}} & \multirow{2}{*}{\multicolumn{4}{|c|}{$\begin{array}{c}\text { Small Thorns }{ }^{2} \\
\text { Machine Harvest Number }\end{array}$}} \\
\hline & & & & & & & & & & & & \\
\hline & 1 & 2 & 3 & 4 & 1 & 2 & 3 & 4 & 1 & 2 & 3 & 4 \\
\hline & \multicolumn{12}{|c|}{1998} \\
\hline 1. Early floricane removal; Feb-trained primocanes (+PeF-Feb) & \multicolumn{4}{|c|}{0} & 2.4 & 4.8 & 5.6 & 2.8 & $1.8 \mathrm{~b}^{5}$ & $2.5 \mathrm{~b}$ & $1.7 \mathrm{~b}$ & $3.4 \mathrm{~b}$ \\
\hline 2. No floricane removal; Aug-trained primocanes (+P+F-Aug) & \multicolumn{4}{|c|}{0.1} & 6.9 & 7.3 & 21.0 & 7.0 & $3.1 \mathrm{~b}$ & $1.9 \mathrm{~b}$ & $10.4 \mathrm{a}$ & $1.8 \mathrm{~b}$ \\
\hline 3. No floricane removal; Feb-trained primocanes $(+\mathrm{P}+\mathrm{F}-\mathrm{Feb})$ & \multicolumn{4}{|c|}{0.1} & 3.8 & 8.6 & 11.7 & 5.6 & $3.2 \mathrm{~b}$ & $0.3 \mathrm{~b}$ & $2.3 \mathrm{~b}$ & $3.2 \mathrm{~b}$ \\
\hline \multicolumn{13}{|l|}{ Significance ${ }^{4}$} \\
\hline Treatment (T) & \multicolumn{4}{|c|}{ NS } & \multicolumn{4}{|c|}{ ** } & \multicolumn{4}{|c|}{ NS } \\
\hline Machine harvest no. (D) & \multicolumn{4}{|c|}{ NS } & \multirow{2}{*}{\multicolumn{4}{|c|}{$* * *$}} & \multicolumn{4}{|c|}{$*$} \\
\hline \multirow[t]{2}{*}{$\mathrm{T} \times \mathrm{D}$} & \multicolumn{4}{|c|}{ NS } & & & & & \multicolumn{4}{|c|}{ ** } \\
\hline & \multicolumn{12}{|c|}{1999} \\
\hline 1. Early floricane removal; Feb-trained primocanes (+PeF-Feb) & $0 \mathrm{~b}$ & $0 \mathrm{~b}$ & $29.0 \mathrm{a}$ & $11.3 \mathrm{~b}$ & & & & & & & 39.6 & \\
\hline 2. No floricane removal; Aug-trained primocanes (+P+F-Aug) & $0 \mathrm{~b}$ & $0.8 \mathrm{~b}$ & $3.5 \mathrm{~b}$ & $3.3 \mathrm{~b}$ & & & & & & & 29.0 & \\
\hline 3. No floricane removal; Feb-trained primocanes $(+\mathrm{P}+\mathrm{F}-\mathrm{Feb})$ & $0.8 \mathrm{~b}$ & $0.3 \mathrm{~b}$ & $0.5 \mathrm{~b}$ & $6.0 \mathrm{~b}$ & & & & & & & 31.4 & \\
\hline \multicolumn{13}{|l|}{ Significance } \\
\hline Treatment $(\mathrm{T})$ & \multicolumn{4}{|c|}{ * } & \multicolumn{4}{|c|}{ NS } & \multicolumn{4}{|c|}{ NS } \\
\hline Machine harvest no. (D) & \multicolumn{4}{|c|}{ * } & \multicolumn{4}{|c|}{ NS } & \multicolumn{4}{|c|}{ NS } \\
\hline \multirow[t]{2}{*}{$\mathrm{T} \times \mathrm{D}$} & \multicolumn{4}{|c|}{ * } & & & & & & & NS & \\
\hline & & & & & & & 00 & & & & & \\
\hline 1. Early floricane removal; Feb-trained primocanes (+PeF-Feb) & $0 \mathrm{~b}$ & $0 \mathrm{~b}$ & $0 \mathrm{~b}$ & $0.8 \mathrm{~b}$ & 7.5 & 9.0 & 17.5 & 21.5 & $\mathrm{Na}^{6}$ & na & na & na \\
\hline 2. No floricane removal; Aug-trained primocanes (+P+F-Aug) & $0.3 \mathrm{~b}$ & $0.5 \mathrm{~b}$ & $1.8 \mathrm{a}$ & $0.5 \mathrm{~b}$ & 11.3 & 11.3 & 26.5 & 35.8 & na & na & na & na \\
\hline 3. No floricane removal; Feb-trained primocanes $(+\mathrm{P}+\mathrm{F}-\mathrm{Feb})$ & $0 \mathrm{~b}$ & $0.3 \mathrm{~b}$ & $0 \mathrm{~b}$ & $0 \mathrm{~b}$ & 7.3 & 6.0 & 18.5 & 21 & na & na & na & na \\
\hline Significance & & & & & & & & & & & & \\
\hline Treatment $(\mathrm{T})$ & & & & & & & & & & & - & \\
\hline Machine harvest no. (D) & & & & & & & & & & & - & \\
\hline $\mathrm{T} \times \mathrm{D}$ & & & & & & & & & & & - & \\
\hline
\end{tabular}


Primocane training in August ( $+\mathrm{P}+\mathrm{F}-\mathrm{Aug})$ compared to February $(+\mathrm{P}+\mathrm{F}-\mathrm{Feb})$ led to a higher percent bud break in 1998 but not in 1999 or 2000 (Table 2). There was no effect of training time on shoot length or fruit per lateral in these new-over-old treatments in any year. However, training primocanes in August (+P+F-Aug) decreased berry weight in 2000 but increased yield in 1999 and 2000 compared to training in February (+P+F-Feb). The impact of training time on yield of 'Marion' has been inconsistent in our various studies $[14,16]$, perhaps due to differences in cultural or environmental factors.

Yields were considerably reduced in 1999 compared to 1998, likely due to winter cold injury to canes and buds after a prolonged period of cold temperatures ranging from -7 to $-10{ }^{\circ} \mathrm{C}$ from December 19 to 23, 1998 [24]. 'Marion' blackberry is relatively sensitive to winter cold injury because it has a low chilling requirement [36] and can experience cane or bud damage at temperatures at -5 to $-22{ }^{\circ} \mathrm{C}[12,13]$. Significant yield reduction of 'Marion' has been observed in grower fields [11] and other research trials [16] at similar temperatures. The stress and damage to primocanes that occur during training to the trellis wires are thought to increase risk of winter cold injury [9,16]. In 1999 and 2000, the lowest yield was in the industry standard of pruning out dead floricanes after harvest and training the primocanes to the trellis wires in February (Table 2).

\subsection{Experiment 3}

Growing 'Marion' blackberry at $1.5 \mathrm{~m}$ in the row in AY production compared to EY production increased the number of floricanes per plant, reduced average cane length and percent bud break (2003 only), had inconsistent effects on berry weight and increased yield per plant and per hectare only in 2003 (Table 4).

In AY production, increasing planting density to $0.6 \mathrm{~m}$ in the row (treatment 2) had inconsistent effects on yield and its components compared to the $1.5 \mathrm{~m}$ spacing (treatment 4; Table 4). While the highest planting density reduced the number of floricanes (in 2002-2003), average berry weight was less (2003-2004) and yield per plant was reduced (all years), leading to a significantly higher yield per hectare only in 2002 compared to the $1.5 \mathrm{~m}$ spacing. In general, spacing plants at $0.9 \mathrm{~m}$ led to a similar response as plants at $0.6 \mathrm{~m}$, particularly in yield per hectare.

Topping the primocanes of plants spaced at $0.6 \mathrm{~m}$ (treatment 1 ), decreased average cane length and the nodes per cane compared to untopped plants at $0.6 \mathrm{~m}$ (treatment 2), only in 2003 (Table 4). Topping increased percent bud break in 2 of 3 years but there was no effect of topping on yield per plant in any year. However, topping primocanes increased yield per hectare compared to untopped canes at $0.6 \mathrm{~m}$ plant spacing in 2003 , likely due to the greater average berry weight in this treatment.

Yield declined in all of the AY treatments from 2002-2003 to 2004, leading to no production system effect on yield per hectare in 2004. The cause of the yield decline, in the AY treatments in particular, is not clear, as there was no evidence of injurious cold temperatures in winter 2003-2004 (data not shown). Since there was no primocane suppression in any of these treatments, this common practice was added in subsequent years to try to optimize primocane growth (cane length) with other possible positive benefits documented with recutting or suppressing primocanes in the off year (Table $5 ;[12,14]$ ).

Starting in 2004 (off year), suppression dates were chosen with a goal of finding a combination of in-row spacing and suppression date to get sufficient primocane growth to fill the canopy without excess growth. In the AY production systems, a new flush of primocanes grew after the mowing or suppression date (removal of existing primocanes). Plants grown at $1.5 \mathrm{~m}$ in the row in an EY production system did not have the primocanes suppressed by re-cutting as mechanical suppression cannot be done practically in this system. While growers do use chemical suppressants (contact herbicides; [17]) with a goal of improving machine harvest efficiency [2], chemical suppression delays subsequent primocane emergence relative to mechanical suppression. 
Table 4. Effect of in-row spacing on yield and its components of 'Marion' trailing blackberry grown in alternate year (AY) production as compared to every year (EY) production from 2002-2004 at Oregon State University's North Willamette Research and Extension Center $(n=5)$.

\begin{tabular}{|c|c|c|c|c|c|c|c|c|}
\hline Treatment $^{1}$ & $\begin{array}{l}\text { Floricanes } \\
\text { (no./plant) }\end{array}$ & $\begin{array}{c}\text { Cane Length } \\
\text { (m) }\end{array}$ & $\begin{array}{c}\text { Nodes } \\
\text { (no./cane) }\end{array}$ & $\begin{array}{c}\text { Bud Break } \\
(\%)\end{array}$ & $\begin{array}{c}\text { Fruit } \\
\text { (no./lateral) }\end{array}$ & $\begin{array}{l}\text { Berry wt. } \\
\text { (g) }\end{array}$ & $\begin{array}{c}\text { Yield } \\
\text { (kg/plant) }\end{array}$ & $\begin{array}{c}\text { Yield } \\
\left(\mathbf{k g} \cdot \mathrm{ha}^{-1}\right)\end{array}$ \\
\hline & \multicolumn{8}{|c|}{2002} \\
\hline 1. AY at $0.6 \mathrm{~m}$ Primocanes topped & $9.8 c^{3}$ & 5.7 & 74.6 & 42.0 & 8.0 & $4.07 \mathrm{ab}$ & $4.11 \mathrm{~b}$ & $22,100 \mathrm{a}$ \\
\hline 2. AY at $0.6 \mathrm{~m}$ & $12.0 \mathrm{bc}$ & 5.6 & 69.6 & 43.5 & 7.8 & $4.21 \mathrm{a}$ & $4.17 \mathrm{~b}$ & $22,402 \mathrm{a}$ \\
\hline 3. AY at $0.9 \mathrm{~m}$ & $15.0 \mathrm{ab}$ & 5.9 & 77.0 & 46.4 & 9.1 & $4.12 \mathrm{ab}$ & $6.52 \mathrm{a}$ & $21,035 \mathrm{a}$ \\
\hline 4. AY at $1.5 \mathrm{~m}$ & $17.6 \mathrm{a}$ & 5.7 & 72.4 & 46.0 & 8.2 & $4.32 \mathrm{a}$ & $7.47 \mathrm{a}$ & $16,065 \mathrm{~b}$ \\
\hline 5. EY at $1.5 \mathrm{~m}$ & $16.6 \mathrm{a}$ & 6.1 & 82.0 & 47.6 & 8.4 & $3.87 \mathrm{~b}$ & $6.80 \mathrm{a}$ & $14,632 \mathrm{~b}$ \\
\hline \multirow[t]{2}{*}{ Significance $^{2}$} & ** & NS & NS & NS & NS & * & $* *$ & ** \\
\hline & \multicolumn{8}{|c|}{2003} \\
\hline 1. AY at $0.6 \mathrm{~m}$ Primocanes topped & $10.0 \mathrm{~b}$ & $3.3 \mathrm{c}$ & $51.8 \mathrm{~b}$ & $48.6 \mathrm{a}$ & 7.1 & $3.81 \mathrm{~b}$ & $3.92 \mathrm{c}$ & $21,075 \mathrm{a}$ \\
\hline 2. AY at $0.6 \mathrm{~m}$ & $10.4 \mathrm{~b}$ & $5.1 \mathrm{~b}$ & $74.0 \mathrm{a}$ & $39.3 \mathrm{~b}$ & 7.3 & $3.42 \mathrm{c}$ & $3.40 \mathrm{c}$ & 18,299 bc \\
\hline 3. AY at $0.9 \mathrm{~m}$ & $12.8 \mathrm{~b}$ & $5.0 \mathrm{~b}$ & $78.6 \mathrm{a}$ & $36.4 \mathrm{~b}$ & 8.0 & $3.65 \mathrm{bc}$ & $5.57 \mathrm{~b}$ & $17,966 \mathrm{c}$ \\
\hline 4. AY at $1.5 \mathrm{~m}$ & $16.0 \mathrm{a}$ & $4.8 \mathrm{~b}$ & $70.4 \mathrm{ab}$ & $35.9 \mathrm{~b}$ & 7.5 & $3.73 \mathrm{~b}$ & $9.54 \mathrm{a}$ & $20,553 \mathrm{ab}$ \\
\hline 5. EY at $1.5 \mathrm{~m}$ & $5.2 \mathrm{c}$ & $6.2 \mathrm{a}$ & $85.6 \mathrm{a}$ & $48.6 \mathrm{a}$ & 8.3 & $4.74 \mathrm{a}$ & $5.04 \mathrm{~b}$ & $10,838 \mathrm{~d}$ \\
\hline \multirow[t]{2}{*}{ Significance } & $* * *$ & $* *$ & * & $* *$ & NS & $* * *$ & $* * *$ & $* * *$ \\
\hline & \multicolumn{8}{|c|}{2004} \\
\hline 2. AY at $0.6 \mathrm{~m}$ & 8.0 & 7.4 & 125.4 & $36.9 \mathrm{~b}$ & 7.7 & $4.26 \mathrm{c}$ & $1.90 \mathrm{c}$ & 10,231 \\
\hline 3. AY at $0.9 \mathrm{~m}$ & 7.8 & 9.2 & 166.0 & $45.9 \mathrm{a}$ & 7.6 & $4.43 \mathrm{bc}$ & $3.25 \mathrm{~b}$ & 10,500 \\
\hline 4. $\mathrm{AY}$ at $1.5 \mathrm{~m}$ & 14.6 & 9.9 & 172.6 & $34.8 \mathrm{~b}$ & 7.6 & $4.55 \mathrm{~b}$ & $4.54 \mathrm{a}$ & 9766 \\
\hline 5. EY at $1.5 \mathrm{~m}$ & 5.7 & 10.0 & 168.0 & $37.1 \mathrm{~b}$ & 9.2 & $5.00 \mathrm{a}$ & $4.73 \mathrm{a}$ & 10,165 \\
\hline Significance & NS & NS & NS & $* *$ & NS & $* * *$ & $* * *$ & NS \\
\hline
\end{tabular}

${ }^{1}$ In the alternate year (AY) treatment with an in-row spacing of $0.6 \mathrm{~m}$ with "primocanes topped" (treatment 1 ), canes were mechanically topped at $1.8 \mathrm{~m}$ once they grew approximately

$0.15 \mathrm{~m}$ beyond the top trellis wire, during the growing season (in mid- to late-June). No primocane suppression or topping was done in the other treatments; ${ }^{2} \mathrm{NS}=$ non-significant; $^{*}, * *, * * * *$ indicates significance at $p<0.05,0.01$ and 0.001 , respectively; ${ }^{3}$ Means followed by the same letter within year are not significantly different $(p \geq 0.05)$. 
Table 5. Effect of in-row spacing on yield and its components of 'Marion' trailing blackberry grown in alternate year (AY) production with primocanes suppressed or topped as compared to every year (EY) production from 2005-2008 at Oregon State University's North Willamette Research and Extension Center $(n=5)$.

\begin{tabular}{|c|c|c|c|c|c|c|c|c|}
\hline \multirow{2}{*}{ Treatment $^{1}$} & Floricanes & Cane Length & Nodes & BUD BREAK & Fruit & Berry wt. & Yield & Yield \\
\hline & (no./plant) & (m) & (no./cane) & $(\%)$ & (no./lateral) & (g) & (kg/plant) & $\left(\mathrm{kg} \cdot \mathrm{ha}^{-1}\right)$ \\
\hline & \multicolumn{8}{|c|}{2005} \\
\hline 1. AY at $0.6 \mathrm{~m}$ Primocanes topped (no Sup.) & 6.6 & $7.1 \mathrm{ab}^{3}$ & $116.8 \mathrm{abc}$ & 28.5 & $7.2 \mathrm{~b}$ & $4.43 \mathrm{~b}$ & $2.48 \mathrm{c}$ & 13,309 \\
\hline 2. AY at $0.6 \mathrm{~m}$; Sup. late May & 7.4 & $3.5 \mathrm{~b}$ & $66.2 \mathrm{c}$ & 42.6 & $7.8 \mathrm{~b}$ & $4.52 \mathrm{~b}$ & $2.33 \mathrm{c}$ & 12,548 \\
\hline 3. AY at $0.9 \mathrm{~m}$; Sup. May & 8.5 & $4.6 \mathrm{~b}$ & $83.4 \mathrm{bc}$ & 36.8 & $7.4 \mathrm{~b}$ & $4.42 \mathrm{~b}$ & $4.03 \mathrm{~b}$ & 12,989 \\
\hline 4. AY at $1.5 \mathrm{~m}$; Sup. April & 8.1 & $8.7 \mathrm{a}$ & $137.4 \mathrm{ab}$ & 27.9 & $8.3 \mathrm{ab}$ & $4.70 \mathrm{~b}$ & $5.61 \mathrm{a}$ & 12,070 \\
\hline 5. EY at $1.5 \mathrm{~m}$; no Sup. & 5.6 & $10.9 \mathrm{a}$ & $167.8 \mathrm{a}$ & 35.9 & $9.4 \mathrm{a}$ & $5.49 \mathrm{a}$ & $5.25 \mathrm{a}$ & 11,300 \\
\hline \multirow[t]{2}{*}{ Significance $^{2}$} & NS & $* *$ & * & NS & * & $* * *$ & $* * *$ & NS \\
\hline & \multicolumn{8}{|c|}{2006} \\
\hline 1. AY at $0.6 \mathrm{~m}$ Primocanes topped (no Sup.) & $5.1 \mathrm{~b}$ & 6.3 & $91.8 \mathrm{ab}$ & $68.6 \mathrm{a}$ & 7.1 & $4.39 \mathrm{c}$ & $2.10 \mathrm{c}$ & $11,316 \mathrm{a}$ \\
\hline 2. AY at $0.6 \mathrm{~m}$; Sup. late May & $6.5 \mathrm{~b}$ & 4.5 & $60.6 \mathrm{~b}$ & $60.5 \mathrm{ab}$ & 7.2 & $4.62 \mathrm{c}$ & $2.05 \mathrm{c}$ & $11,021 \mathrm{a}$ \\
\hline 3. AY at $0.9 \mathrm{~m}$; Sup. May & $8.7 \mathrm{a}$ & 3.6 & $64.4 \mathrm{~b}$ & $54.7 \mathrm{abc}$ & 8.4 & $4.63 \mathrm{bc}$ & $3.24 \mathrm{~b}$ & 9729 a \\
\hline 4. AY at $1.5 \mathrm{~m}$; Sup. April & $10.3 \mathrm{a}$ & 7.2 & $108.2 \mathrm{a}$ & $47.7 \mathrm{bc}$ & 6.9 & $5.06 \mathrm{~b}$ & $4.77 \mathrm{a}$ & 10,262 a \\
\hline 5. EY at $1.5 \mathrm{~m}$; no Sup. & $5.1 \mathrm{~b}$ & 5.5 & $72.8 \mathrm{~b}$ & $37.9 \mathrm{c}$ & 8.5 & $6.10 \mathrm{a}$ & $2.59 \mathrm{c}$ & $5570 \mathrm{~b}$ \\
\hline \multirow[t]{2}{*}{ Significance } & $* * *$ & NS & * & * & NS & $* * *$ & $* * *$ & $* * *$ \\
\hline & \multicolumn{8}{|c|}{2007} \\
\hline 1. AY at $0.6 \mathrm{~m}$ Primocanes topped (no Sup.) & $5.5 \mathrm{c}$ & 6.0 & $210.2 \mathrm{a}$ & $25.8 \mathrm{~b}$ & 7.4 & 4.07 & $3.31 \mathrm{c}$ & 17,787 a \\
\hline 2. AY at $0.6 \mathrm{~m}$; Sup. late May & $7.1 \mathrm{bc}$ & 3.8 & $66.4 \mathrm{c}$ & $47.7 \mathrm{a}$ & 8.1 & 4.17 & $2.27 \mathrm{~d}$ & $12,183 \mathrm{~b}$ \\
\hline 3. AY at $0.9 \mathrm{~m}$; Sup. May & $8.6 \mathrm{~b}$ & 3.7 & $76.4 \mathrm{c}$ & $41.2 \mathrm{a}$ & 9.6 & 4.55 & $3.55 \mathrm{c}$ & $11,461 \mathrm{~b}$ \\
\hline 4. AY at $1.5 \mathrm{~m}$; Sup. April & $12.6 \mathrm{a}$ & 5.7 & $171.8 \mathrm{ab}$ & $25.8 \mathrm{~b}$ & 8.3 & 4.21 & $7.37 \mathrm{a}$ & $15,844 \mathrm{a}$ \\
\hline 5. EY at $1.5 \mathrm{~m}$; no Sup. & $6.9 \mathrm{bc}$ & 5.2 & $118.0 \mathrm{bc}$ & $24.5 \mathrm{~b}$ & 9.5 & 4.55 & $5.56 \mathrm{~b}$ & $11,951 \mathrm{~b}$ \\
\hline \multirow[t]{2}{*}{ Significance } & $* *$ & NS & $* *$ & $* *$ & NS & NS & $* * *$ & $* *$ \\
\hline & \multicolumn{8}{|c|}{2008} \\
\hline 1. AY at $0.6 \mathrm{~m}$ Primocanes topped (no Sup.) & $\mathrm{Na}^{4}$ & na & na & na & na & $3.77 \mathrm{c}$ & $1.77 \mathrm{c}$ & 9527 \\
\hline 2. AY at $0.6 \mathrm{~m}$; Sup. late May & na & na & na & na & na & $3.94 \mathrm{bc}$ & $1.29 \mathrm{c}$ & 6936 \\
\hline 3. AY at $0.9 \mathrm{~m}$; Sup. May & na & na & na & na & na & $4.01 \mathrm{bc}$ & $2.00 \mathrm{bc}$ & 6452 \\
\hline 4. AY at $1.5 \mathrm{~m}$; Sup. April & na & na & na & na & na & $4.13 \mathrm{~b}$ & $3.66 \mathrm{a}$ & 7867 \\
\hline 5. EY at $1.5 \mathrm{~m}$; no Sup. & na & na & na & na & na & $4.48 \mathrm{a}$ & $2.87 \mathrm{ab}$ & 6180 \\
\hline Significance & & & & & & $* *$ & $* *$ & NS \\
\hline
\end{tabular}

${ }^{1}$ In the alternate year (AY) treatment with an in-row spacing of $0.6 \mathrm{~m}$ with "primocanes topped" (treatment 1 ), canes were mechanically topped at $1.8 \mathrm{~m}$ once they grew approximately 0.15 $\mathrm{m}$ beyond the top trellis wire, during the growing season (in mid- to late-June); there was no primocane suppression. In the other AY treatments (2-4), primocane suppression date varied with in-row spacing (date indicated) with a goal of choosing a combination that would fill the canopy without excess growth; primocanes were not topped in these AY treatments. No primocane suppression or topping was done in the EY treatment $5 ;^{2} \mathrm{NS}=$ non-significant; ${ }^{*}, * *, * * *$ indicates significance at $p<0.05,0.01$ and 0.001 , respectively; ${ }^{3}$ Means followed by the same letter within year are not significantly different $(p \geq 0.05) ;{ }^{4}$ na indicates data not collected. 
In general, suppressing primocanes by mechanically cutting canes in the off year of an AY system, increased floricane number the following season [14] relative to EY production (Table 5). The fewest number of floricanes per plant was found at the high density. Canes were longer, with more nodes in general, when plants were spaced further apart or were topped (grown at $0.6 \mathrm{~m}$ ) (Table 5). Percent bud break tended to be lower when plants were grown further apart in the row (2006-2007). The number of fruit per lateral was only affected by production system in 2005 when plants at $1.5 \mathrm{~m}$ in the row tended to have a higher number. Despite producing more fruit per lateral, plants in EY production at $1.5 \mathrm{~m}$ also produced larger berries in 2005; berries in this system were also larger in 2006 and 2008 compared to all AY systems.

Yield per plant in the AY systems (treatments 2-4) increased with plant spacing in all years except for 2008 when the $0.6 \mathrm{~m}$ and $0.9 \mathrm{~m}$ spaced systems had a similar yield (Table 5). The production system where plants were spaced at $0.6 \mathrm{~m}$ and primocanes were not suppressed but were topped at the top trellis wire, only produced a higher yield per plant than plants at $0.6 \mathrm{~m}$ with primocanes suppressed in May-June in 2007 when these plants produced much longer canes.

Yield per hectare was only affected by production system in 2006 and 2007 (Table 5). In 2006, all of the AY production systems had a similar yield, regardless of in-row spacing, whereas the EY production system had the lowest yield. The lowest recorded temperature for the winter of $2005-2006$ was $-7.2^{\circ} \mathrm{C}$ on 15-17 December 2005 and -6.9 to $-5.3^{\circ} \mathrm{C}$ on 16-20 February 2006 [24]; these temperatures are low enough to injure 'Marion' [12,13,16], particularly for plants grown in EY production [11]. In addition to low yield, the sensitivity of the $1.5 \mathrm{~m}$, EY production system to winter cold injury was expressed as lower percent bud break than many other treatments (Table 5).

The lowest recorded temperature for the winter of $2006-2007$ was $-3.9^{\circ} \mathrm{C}$ on 28 November and 17-18 December 2006 and -6.1 to $-3.3^{\circ} \mathrm{C}$ on $12-16$ January and -3.9 to $-3.3^{\circ} \mathrm{C}$ on $1-2$ February 2007 . In 2007 , the $0.6 \mathrm{~m}$ in-row spacing with primocanes topped and the $1.5 \mathrm{~m}$ spacing with primocanes suppressed in April had the greatest yield per hectare.

In 2008, yield per hectare was considerably less than the prior year and there was no effect of production system. There were no apparent injurious cold temperatures the prior winter to account for the reduced yield [24]. There was a trend $(p=0.06)$ for plants at $1.5 \mathrm{~m}$ in EY production to have the lowest yield and those at $0.6 \mathrm{~m}$ in AY (topped) to have the highest yield (Table 5).

Although the plants grown in AY production had a significantly higher yield per hectare during this study, particularly in years preceded by winter cold injury, growers producing 'Marion' in AY production systems will only have half their planted area fruiting in any given year. From 2005-2008, cumulative yield for the $1.5 \mathrm{~m}$ EY treatment was $35,000 \mathrm{~kg} \cdot \mathrm{ha}^{-1}$ (Table 5). Adding primocane suppression to the AY treatments during this period led to cumulative yields of $25,976,21,349,20,320$ and $23,027 \mathrm{~kg} \cdot \mathrm{ha}^{-1}$ for the $0.6 \mathrm{~m}$ (topped), $0.6 \mathrm{~m}, 0.9 \mathrm{~m}$ and $1.5 \mathrm{~m} \mathrm{AY}$ systems, respectively (Table 5; half of reported yield in each year). Thus, despite plants showing evidence of greater winter cold tolerance in some years, AY production only produced $66 \%$ of the yield of EY production, when plants were spaced at $1.5 \mathrm{~m}$ in the row. There was no significant effect of planting at higher density on cumulative yield. However, planting at $0.6 \mathrm{~m}$ and topping the canes (without primocane suppression) had a significantly higher cumulative yield than all other AY treatments, except plants at $1.5 \mathrm{~m}$.

The $0.6 \mathrm{~m}$ topped AY production treatment reached $74 \%$ of the cumulative yield of the $1.5 \mathrm{~m}$ EY production system. However, this alternative production system may offer economic advantages to the $1.5 \mathrm{~m}$ EY or AY production systems. Alternate year production systems have documented advantages (at $1.5 \mathrm{~m}$ ) including labor savings from being able to train primocanes as they grow in the off-year, reduced pesticide usage (fewer cane diseases) and greater cold hardiness following an off-year (and no risk following an on-year when there are no canes present) $[6,9,12,26]$. The $0.6 \mathrm{~m}$ AY topped system would likely offer these same advantages but be better adapted to mechanization. Canes could be bundled as they grow in the off-year, training them to the trellis. Furthermore, once the bundle of canes grew past the top trellis wire, growers could top the canes using mechanized systems. Currently in the $1.5 \mathrm{~m}$ AY system, canes must be trained to the trellis by hand because they are considerably longer. 
Another option for growers who do not want to top the primocanes would be to space new plantings at $0.6 \mathrm{~m}$ and then mechanically suppress (re-cut) primocanes in late May. Mechanically suppressing primocanes in mid-April is a current practice in AY plantings spaced at $1.5 \mathrm{~m}$ [9]. However, doing this later in the season for the higher density, $0.6 \mathrm{~m}$ planting would lead to shorter canes that do not need to be trained other than bundling them to the top wire. While all of the AY systems reduced berry weight, this has not been an issue in the processed fruit market to date.

Funding: This research was funded by the Oregon Raspberry and Blackberry Commission and the Northwest Center for Small Fruits Research.

Acknowledgments: The author appreciates the assistance of Gil Buller, former Senior Faculty Research Assistant (SFRA) and Amanda Vance, SFRA, at the North Willamette Research and Extension Center, Oregon State University.

Conflicts of Interest: The author declares no conflict of interest. The funding sponsors had no role in the design of the study; in the collection, analyses, or interpretation of data; in the writing of the manuscript and in the decision to publish the results.

\section{References}

1. Oregon Agriculture Facts and Figures. Available online: https://www.nass.usda.gov/Statistics_by_State/ Oregon/Publications/facts_and_figures/facts_and_figures.pdf (accessed on 26 October 2017).

2. Strik, B.; Stanton, M. Crop production. In Blackberries and Their Hybrids; Hall, H., Funt, D., Eds.; CABI Press: Oxfordshire, UK, 2017; pp. 245-265.

3. Finn, C.E.; Clark, J.R. Cultivar development and selection. In Blackberries and Their Hybrids; Hall, H., Funt, D., Eds.; CABI Press: Oxfordshire, UK, 2017; pp. 63-92.

4. Finn, C.; Strik, B.; Lawrence, F. 'Marion' trailing blackberry. Fruit Var. J. 1997, 51, 130-133.

5. Strik, B.; Buller, G. Reducing thorn contamination in machine-harvested 'Marion' blackberry. Acta Hortic. 2002, 585, 677-681. [CrossRef]

6. Julian, J.; Seavert, C.; Strik, B.; Kaufman, D. Berry Economics: Establishing and Producing 'Marion' Blackberries in the Willamette Valley, Oregon; EM 8773; Oregon State University Extension Service: Corvallis, OR, USA, 2009.

7. Costs of Producing Trailing Blackberries for Organic, Machine-Harvested Processed Markets in Oregon. Available online: https://archive.extension.oregonstate.edu/nwrec/programs/berry-crops (accessed on 11 July 2018).

8. Strik, B. Growth and development. In Blackberries and Their Hybrids; Hall, H., Funt, D., Eds.; CABI Press: Oxfordshire, UK, 2017; pp. 17-34.

9. Strik, B.; Takeda, F.; Gao, G. Pruning and training. In Blackberries and Their Hybrids; Hall, H., Funt, D., Eds.; CABI Press: Oxfordshire, UK, 2017; pp. 169-201.

10. Cortell, J.M.; Strik, B.C. Effect of floricane number in 'Marion' trailing blackberry. II. Yield components and dry mass partitioning. J. Am. Soc. Hortic. Sci. 1997, 122, 611-615.

11. Bell, N.; Nelson, E.; Strik, B.C.; Martin, L. Assessment of Winter Injury to Berry Crops in Oregon, 1991; Agricultural Experiment Station Special Report; Agricultural Experiment Station, Oregon State University: Corvallis, OR, USA, 1992; Volume 902.

12. Bell, N.C.; Strik, B.C.; Martin, L.W. Effect of primocane suppression date on 'Marion' trailing blackberry. II. Cold hardiness. J. Am. Soc. Hortic. Sci. 1995, 120, 25-27.

13. Cortell, J.M.; Strik, B.C. Effect of floricane number in 'Marion' trailing blackberry. I. Primocane growth and cold hardiness. J. Am. Soc. Hortic. Sci. 1997, 122, 604-610.

14. Bell, N.C.; Strik, B.C.; Martin, L.W. Effect of primocane suppression date on 'Marion' trailing blackberry. I. Yield components. J. Am. Soc. Hortic. Sci. 1995, 120, 21-24.

15. Takeda, F.; Strik, B.; Peacock, D.; Clark, J.R. Patterns of floral bud development in canes of erect and trailing blackberry. J. Am. Soc. Hortic. Sci. 2002, 128, 3-7.

16. Dixon, E.K.; Strik, B.C.; Valenzuela-Estrada, L.R.; Bryla, D.R. Weed management, training, and irrigation practices for organic production of trailing blackberry: I. Mature plant growth and fruit production. HortScience 2015, 50, 1165-1177.

17. Pacific Northwest Weed Management Handbook. Available online: http://pnwhandbooks.org/weed (accessed on 10 June 2018). 
18. Crandall, P.C.; Chamberlain, J.D.; Garth, J.K.L. The effects of primocane suppression on growth, yield, and chemical composition of red raspberries. J. Am. Soc. Hortic. Sci. 1980, 99, 524-526.

19. Lawson, H.M.; Wisemann, J.S. Techniques for the control of cane vigor in red raspberry in Scotland: Effects of timing and frequency of cane removal treatments on growth and yield in cv. Glen Cova. J. Hortic. Sci. 1983, 58, 247-260. [CrossRef]

20. Waister, P.D.; Cormack, M.R.; Sheets, W.A. Competition between fruiting and vegetative phases in the red raspberry. J. Hortic. Sci. 1977, 52, 75-85. [CrossRef]

21. Wright, C.J.; Waister, P.D. Within-plant competition in red raspberry. I. Primocane growth. J. Hortic. Sci. 1982, 57, 437-442. [CrossRef]

22. Wright, C.J.; Waister, P.D. Within-plant competition in red raspberry. II. Fruiting cane growth. J. Hortic. Sci. 1982, 57, 443-448. [CrossRef]

23. Hardiness Zone Map. Available online: http:// planthardiness.ars.usda.gov/PHZMWeb/InteractiveMap. aspx (accessed on 5 January 2018).

24. AgriMet Weather Station Website. Available online: www.usbr.gov/pn/agrimet/agrimetmap/araoda.html (accessed on 8 June 2018).

25. Hart, J.; Strik, B.C.; Rempel, H. Caneberries. Nutrient Management Guide; EM8903-E; Oregon State University Extension Service: Corvallis, OR, USA, 2006.

26. Strik, B.C.; Finn, C.E. Blackberry production systems-A worldwide perspective. Acta Hortic. 2012, 946, 341-348. [CrossRef]

27. Bryla, D.R.; Strik, B.C. Do primocanes and floricanes compete for soil water in blackberry? Acta Hortic. 2008, 777, 477-482. [CrossRef]

28. Pacific Northwest Insect Management Handbook. Available online: http://pnwhandbooks.org/insect (accessed on 10 June 2018).

29. Pacific Northwest Plant Disease Management Handbook. Available online: http://pnwhandbooks.org/ plantdisease (accessed on 10 June 2018).

30. Dixon, E.K.; Strik, B.C.; Bryla, D.R. Weed management, training, and irrigation practices for organic production of trailing blackberry: III. Accumulation and removal of aboveground biomass, carbon, and nutrients. HortScience 2016, 51, 51-66.

31. Harkins, R.H.; Strik, B.C.; Bryla, D.R. Weed management practices for organic production of trailing blackberry: II. Accumulation and loss of biomass and nutrients. HortScience 2014, 49, 35-43.

32. Strik, B.C.; Bryla, D.R. Uptake and partitioning of nutrients in blackberry and raspberry and evaluating plant nutrient status for accurate assessment of fertilizer requirements. HortTechnology 2015, 25, 452-459.

33. Mohadjer, P.; Strik, B.C.; Zebarth, B.J.; Righetti, T.L. Nitrogen uptake, partitioning and remobilization in 'Kotata' blackberries in alternate year production. J. Hortic. Sci. Biotechnol. 2001, 76, 700-708. [CrossRef]

34. Rempel, H.; Strik, B.; Righetti, T. Uptake, partitioning and storage of fertilizer nitrogen in red raspberry as affected by rate and timing of application. J. Am. Soc. Hortic. Sci. 2004, 129, 439-448.

35. Nehrbas, S.R.; Pritts, M.P. Effect of pruning system on yield components of two summer-bearing raspberry cultivars. J. Am. Soc. Hortic. Sci. 1988, 113, 314-321.

36. Strik, B.; Cahn, H.; Bell, N.; DeFrancesco, J. Caneberry Research at North Willamette Research and Extension Center-An Update. In Proceedings of the Oregon Horticultural Society, Portland, OR, USA, 27 January 1994; pp. 141-149.

(C) 2018 by the author. Licensee MDPI, Basel, Switzerland. This article is an open access article distributed under the terms and conditions of the Creative Commons Attribution (CC BY) license (http://creativecommons.org/licenses/by/4.0/). 